\title{
Fossils from the Frontier:
}

Decades of museum influence on the paleontology of Florissant fossil beds 


\section{Florissant Fossil Beds, Colorado}

- $34 \mathrm{Ma}$ (late Eocene) deposits

- Lacustrine setting with volcanic activity

- ca. 1800 fossil species from shale and petrified wood

- 5800 published specimens, 330 publications

- 2 hours from Denver! 


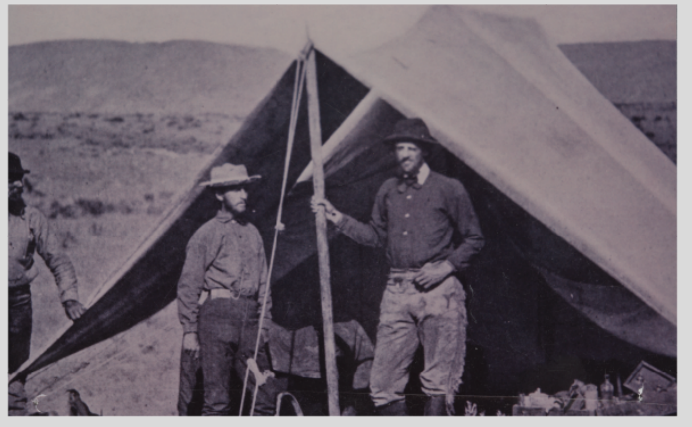

1874

Hayden survey reports Florissant fossils

1877

Princeton and Scudder expeditions

1906-08
Cockerell expeditions

1890

Scudder monograph

Cockerell expeditions
1969

National Monument established

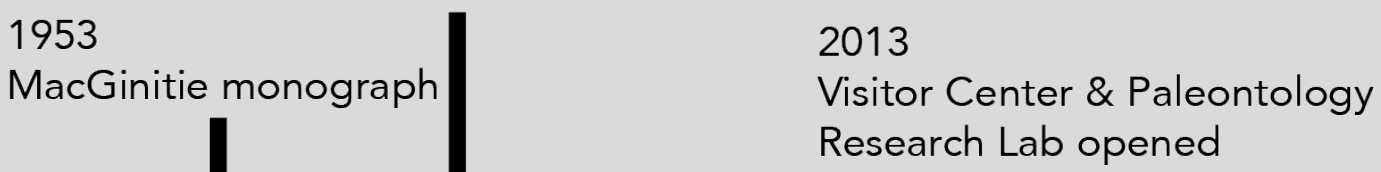

Research Lab opened

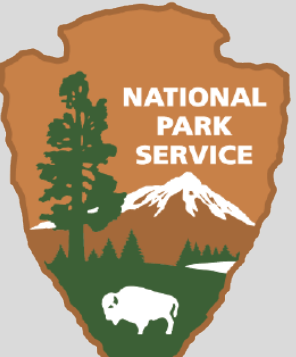

Wickam papers

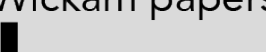

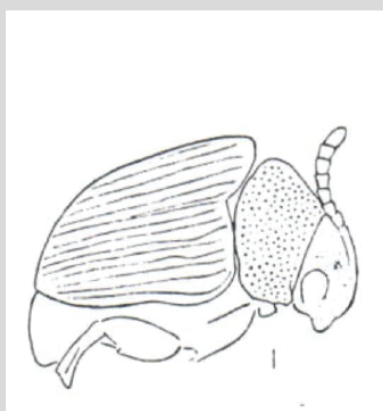

Plate VII

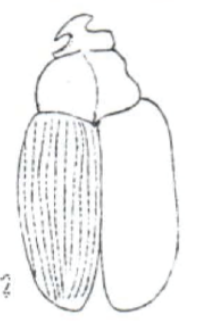

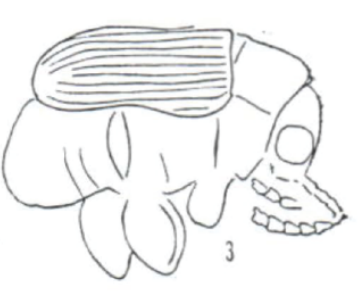




\section{Nineteenth Century Collectors}

- 20-member Princeton Scientific Expedition, July 1877

- Samuel Scudder and Arthur Lakes, August 1877

- Homesteader Charlotte Hill likely the predominant collector

- O.C. Marsh bought fossil plants and insects from Charlotte in 1898
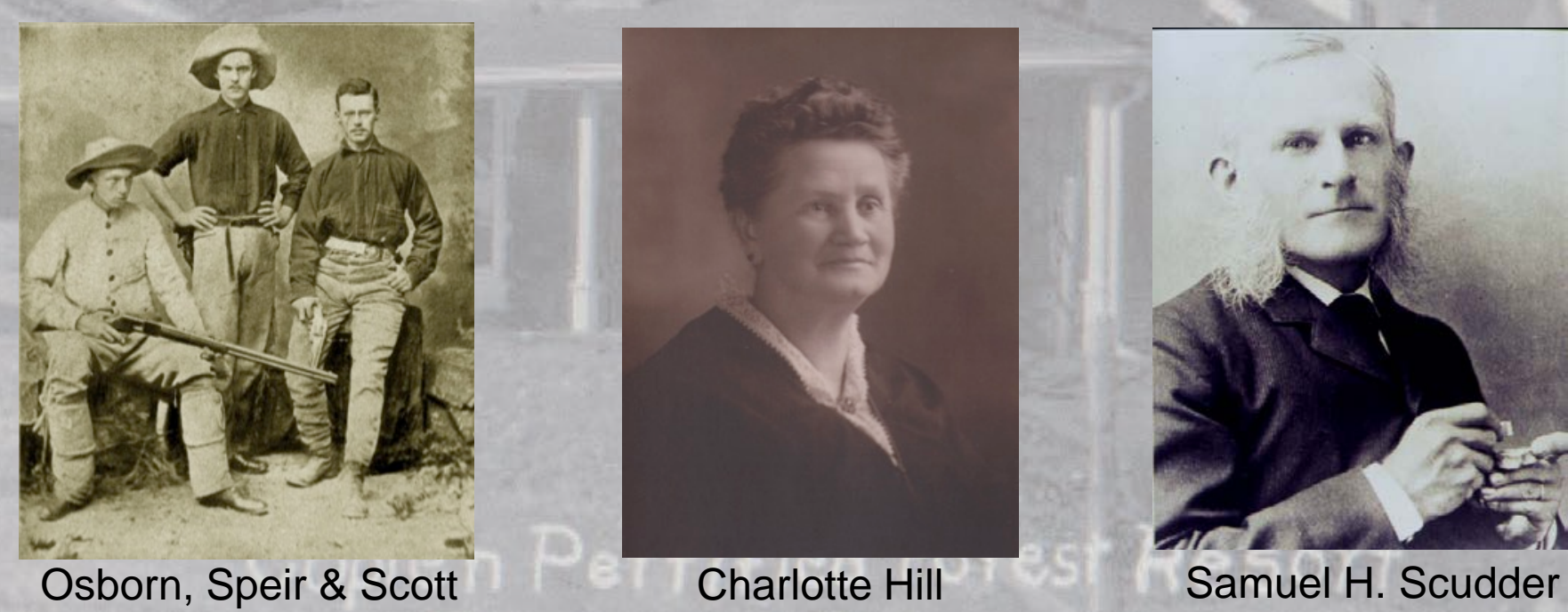

Charlotte Hill

Samuel H. Scudder 


\section{T.D.A. Cockerell}

- Professor at UC Boulder; AMNH and Yale affiliations

- Expeditions to Florissant 1906-1908

- Donated Florissant fossils to various museums

- Advocated for science, paleontology, and an integrated network of museums
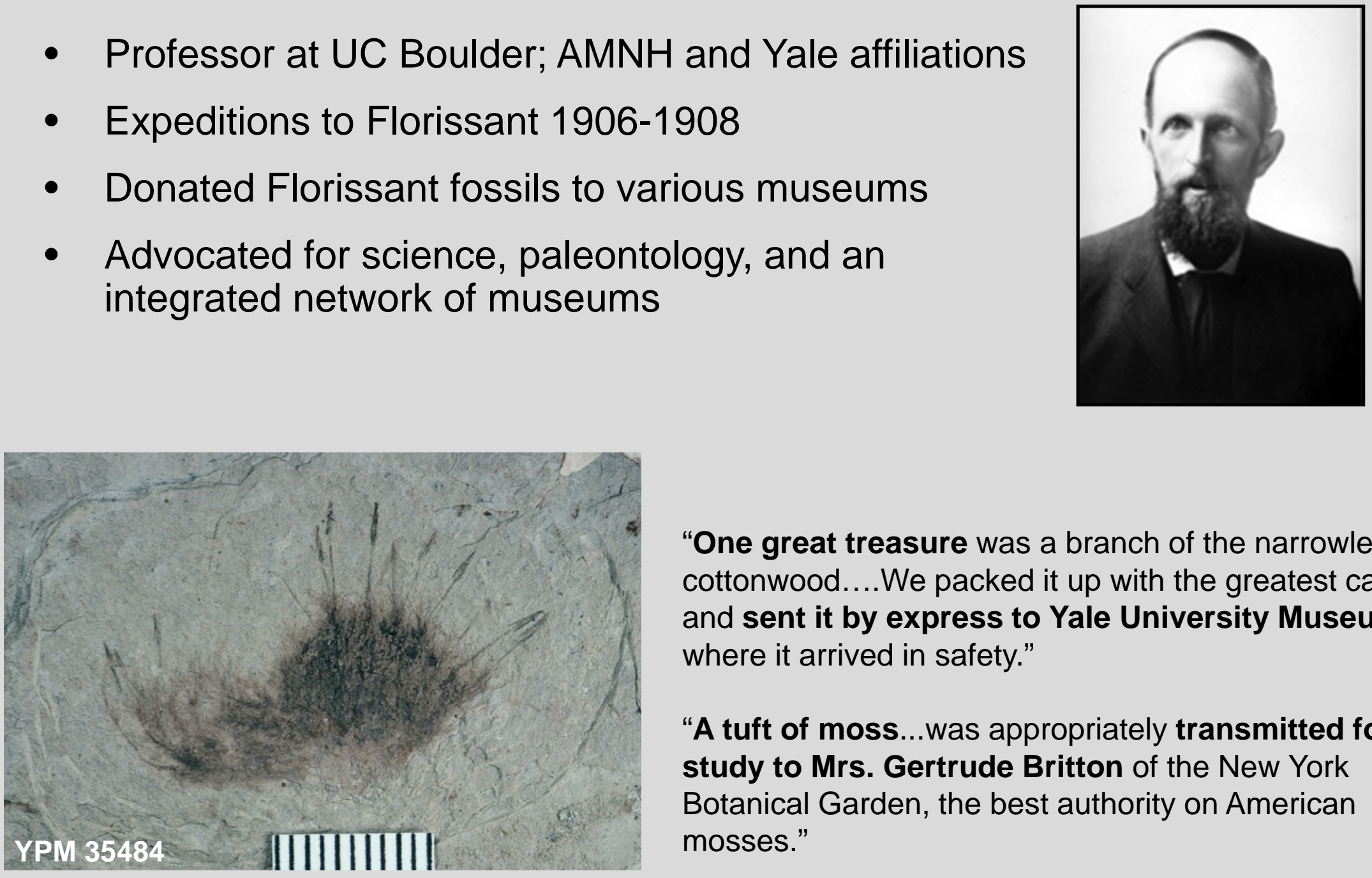

"One great treasure was a branch of the narrowleaved cottonwood....We packed it up with the greatest care, and sent it by express to Yale University Museum, where it arrived in safety."

"A tuft of moss...was appropriately transmitted for study to Mrs. Gertrude Britton of the New York Botanical Garden, the best authority on American mosses." 


\section{Cockerell's "Pan-American Museum Policy"}

i. Local branch museums

ii. Once central institution

"The National Museum should become national in a larger sense. It seems to me that it should establish branch museums... illustrating the natural history of the regions they represented." Cockerell, 1920
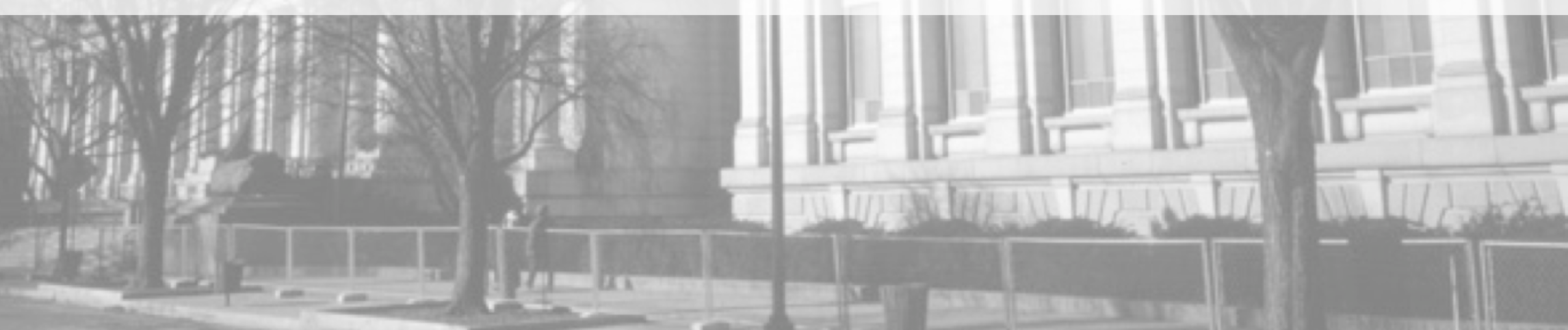


\section{The Diaspora of Florissant Collections}

- More than 20 museums hold Florissant fossils

- McGinitie's plants at UC Berkeley

- Scudder's insects at MCZ, Harvard

- Cockerell's specimens at many institutions 


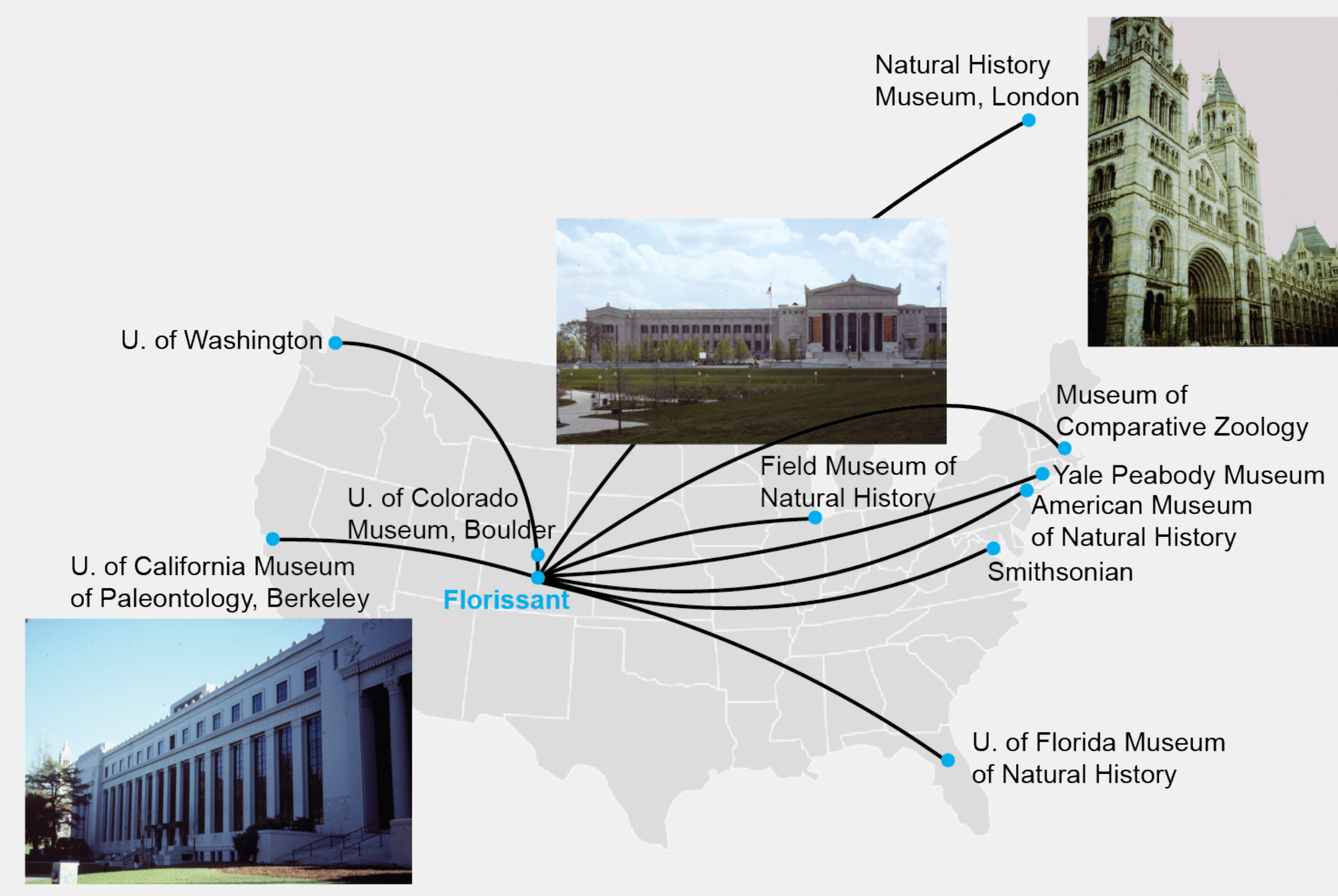




\section{Establishment of the National Monument}

- On-site museum holds ca. 10,000 objects

- Interpretive center hosts educational activities

- Archives document Florissant fossil beds history

- Long-term site monitoring 


\section{A Central Database}

- All Florissant type specimens imaged and databased

- Built with cooperation of 17 museums

- Searchable and publicly accessible

planning.nps.gov/flfo/
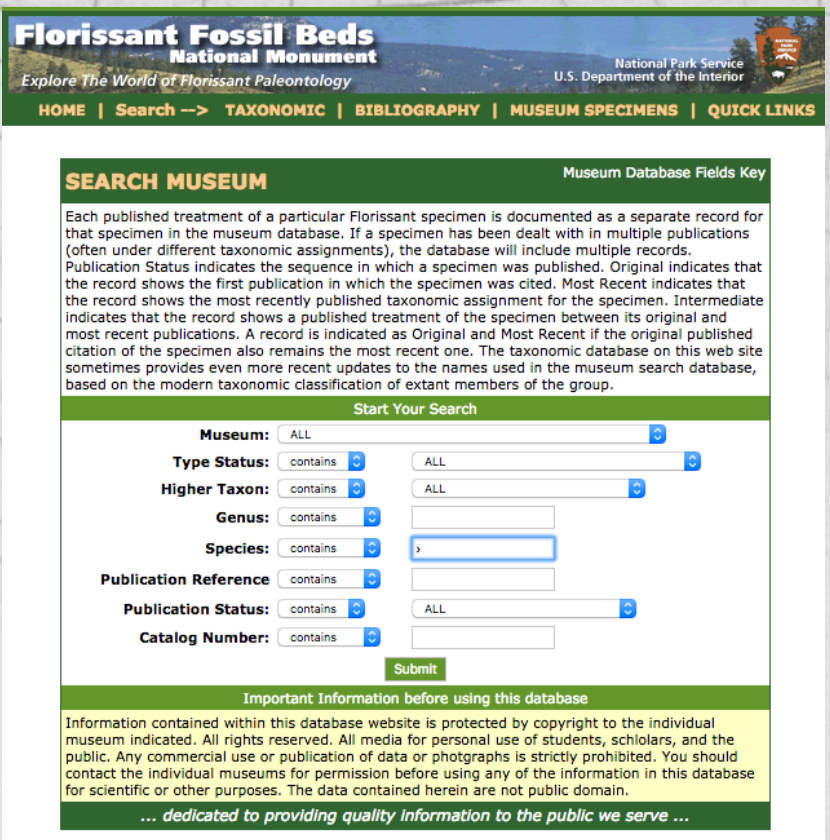

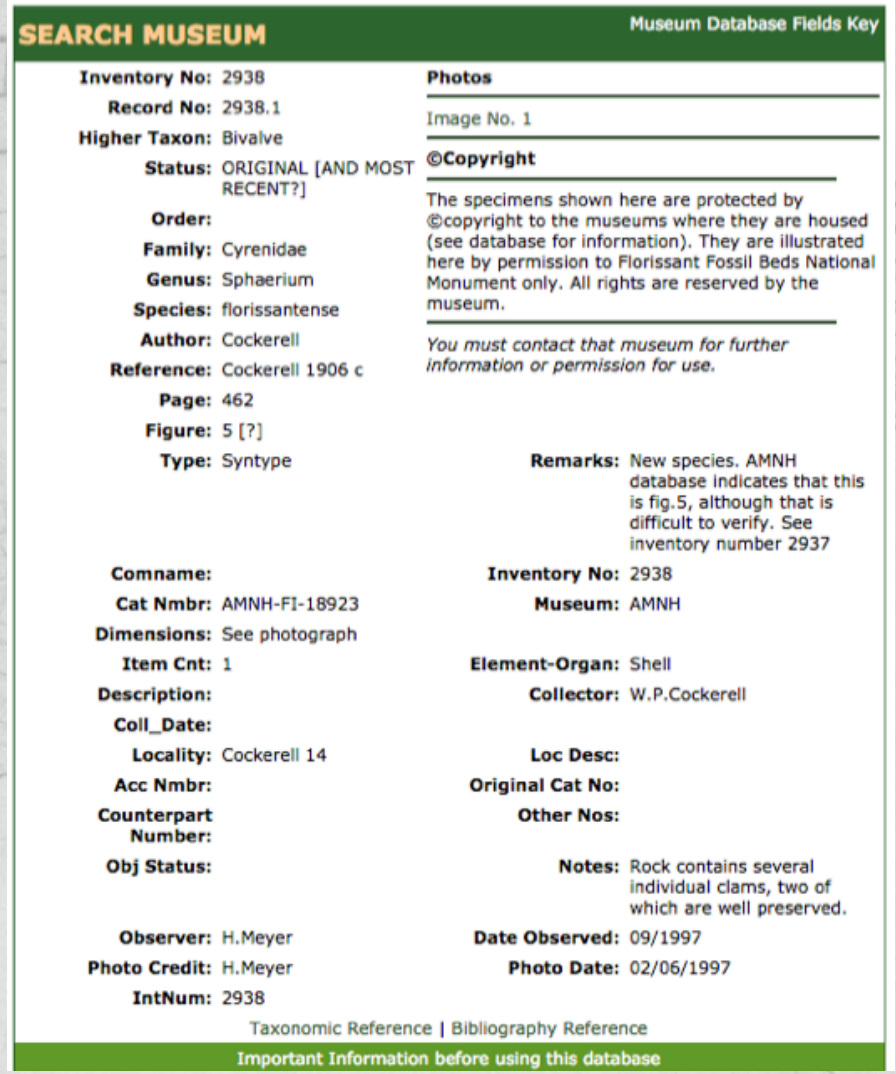




\section{Digitization Collaborations}

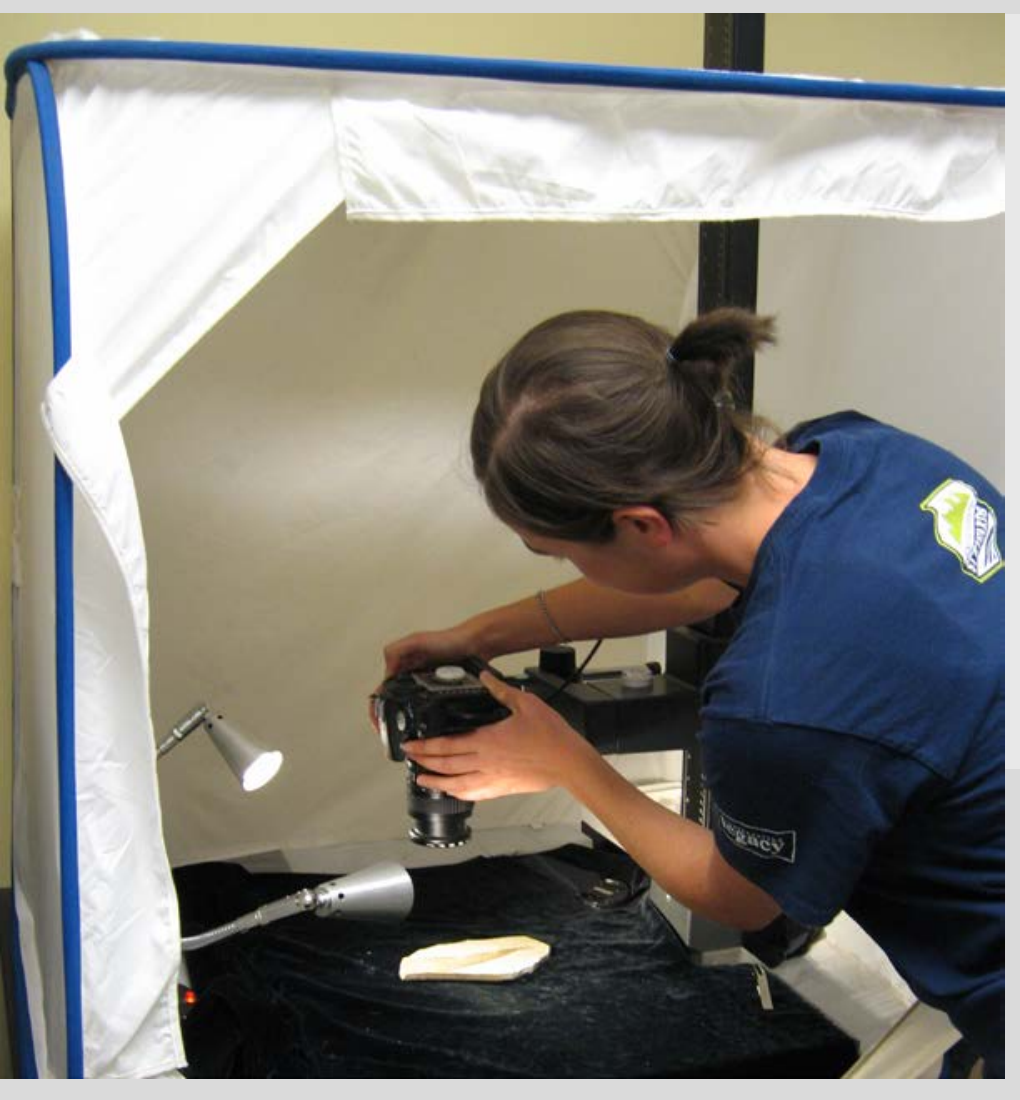

- Fossil Insect Collaborative, 10 museums involved

- Specimen images and museum records uploaded to digital databases

- Data feed into national, NSF-funded database (iDigBio.org/portal)
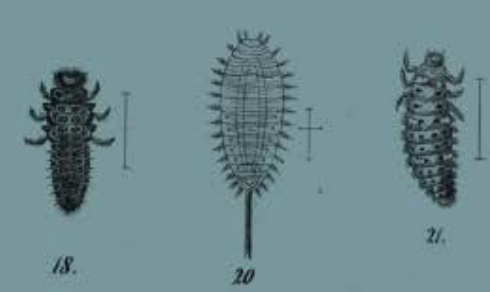


\section{Historic Role of Museums}

- Expedition supporters

- Repositories for frontier fossils

- Ivory towers of research

- Isolated institutions

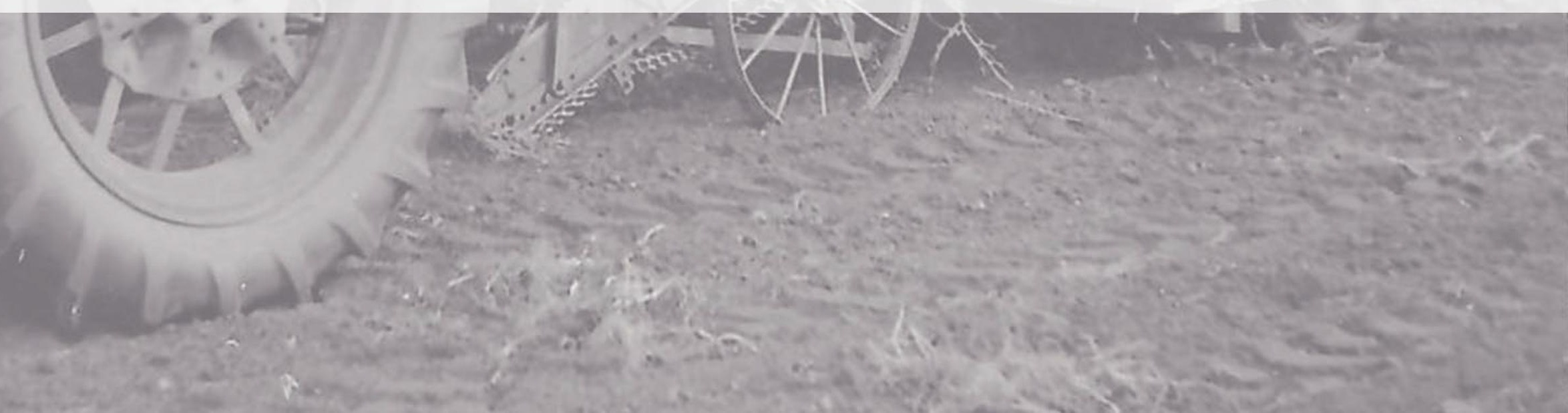




\section{Emerging Role of Museums}

- Small museums with local material

- Interpretation and education for general public

- Data distributors, through integrated digitized collections

- In 2016: federally mandated protectors for park fossils

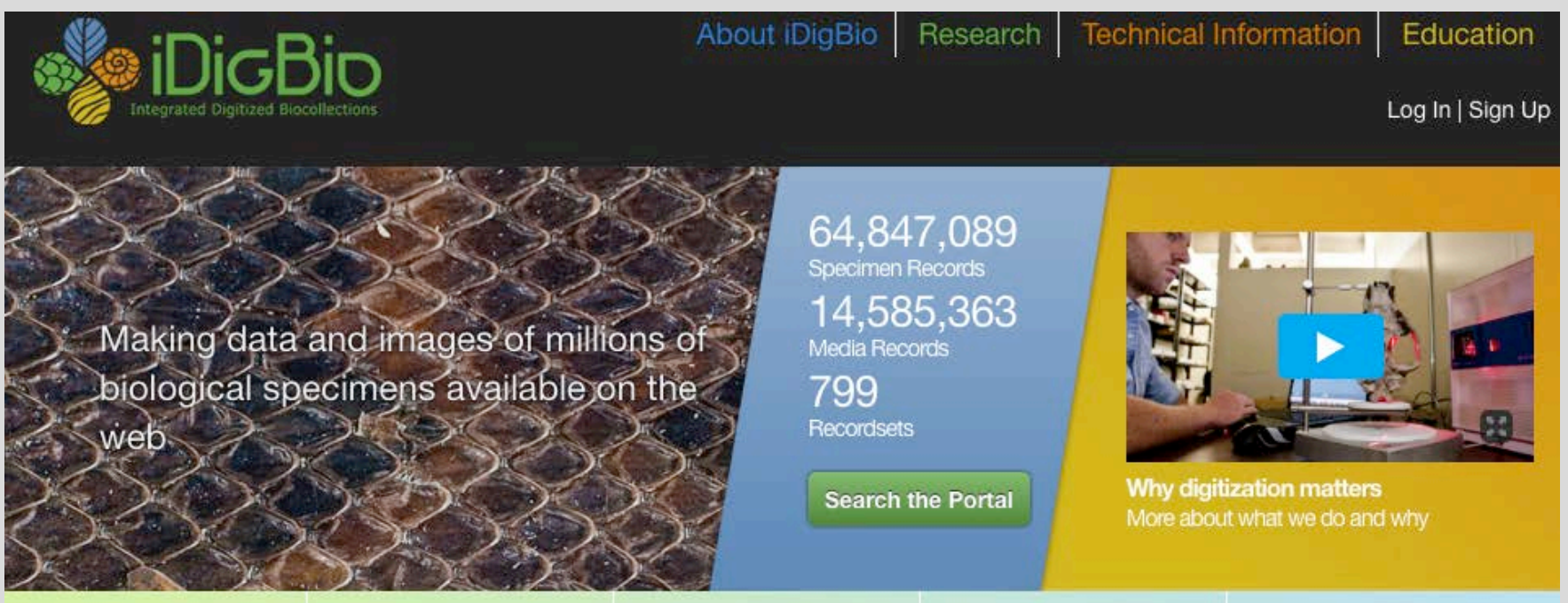

Digitization Learn, share and develop best practices 
The role of a museum "should not be static, that of simply caring for the collections, but intensely dynamic. It should and must be one of the greater influences for human advancement and human welfare....

Could there be a grander function, or one more worthy of public support?"

Cockerell, 1920. "A Policy for the U.S. National Museum," from The Scientific Monthly 10:553-55 


\section{With thanks}

\section{L.}

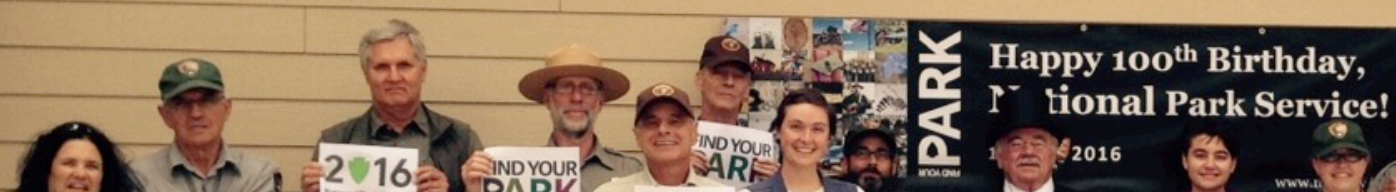

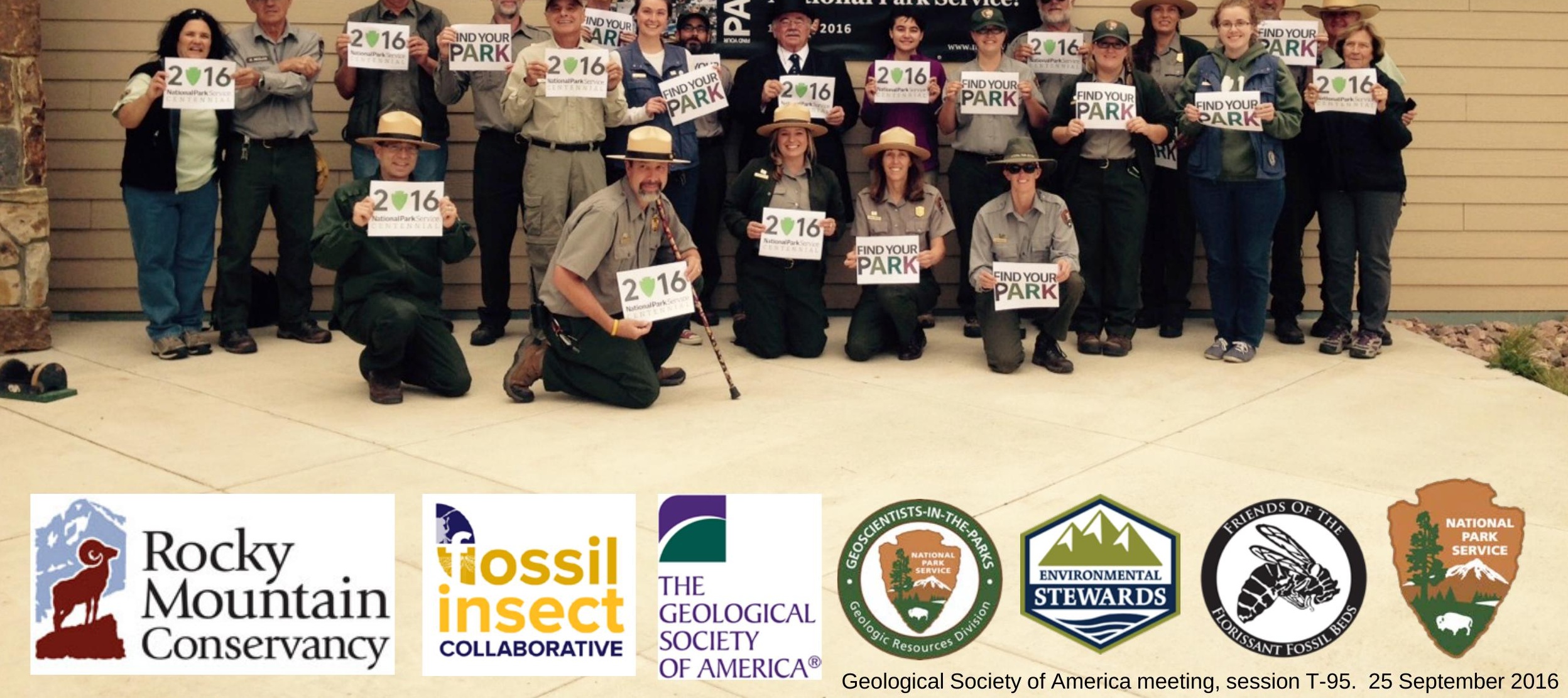

